\title{
Simultaneous detection of alkylamines in the surface ocean and atmosphere of the Antarctic sympagic environment
}

Manuel Dall'Osto ${ }^{1,2,3^{*}}$, Ruth L. Airs ${ }^{4}$, Rachael Beale ${ }^{4}$, Charlotte Cree, Mark F. Fitzsimons ${ }^{5}$, David Beddows ${ }^{2}$, Roy M. Harrison ${ }^{2, \$}$, Darius Ceburnis ${ }^{3}$, Colin O'Dowd ${ }^{3}$, Matteo Rinaldi ${ }^{6}$, Marco Paglione ${ }^{6,7}$, Athanasios Nenes ${ }^{7,8}$, Stefano Decesari ${ }^{6}$ and Rafel Simó ${ }^{1}$

${ }^{1}$ Institute of Marine Sciences, Passeig Marítim de la Barceloneta, 37-49. E08003, Barcelona, Spain; *Email: dallosto@icm.csic.es,

${ }^{2}$ National Center for Atmospheric Sciences, University of Birmingham, Edgbaston, Birmingham, B15 2TT, United Kingdom

${ }^{3}$ School of Physics and Centre for Climate and Air Pollution Studies, Ryan Institute, National University of Ireland Galway, University Road, Galway, Ireland

${ }^{4}$ Plymouth Marine Laboratory, Prospect Place, Plymouth. PL1 3DH. UK

${ }^{5}$ Biogeochemistry Research Centre, University of Plymouth, Drake Circus, Plymouth, PL4 8AA, UK.

${ }^{6}$ Institute of Atmospheric Sciences and Climate, National Research Council, Bologna, Italy.

${ }^{7}$ Institute of Chemical Engineering Sciences, Foundation for Research and Technology Hellas (FORTH/ICE-HT), Patras, Greece

8 Laboratory of Atmospheric Processes and their Impacts, School of Architecture, Civil \& Environmental Engineering, École Polytechnique Fédérale de Lausanne, 1015, Lausanne, Switzerland

${ }^{\$}$ Also at: Department of Environmental Sciences/Centre of Excellence in Environmental Studies, King Abdulaziz University, PO Box 80203, Jeddah, 21589, Saudi Arabia. 
Keywords: Polar biogeochemistry, marine aerosol, ATOFMS, Secondary Aerosols, Southern Ocean, polar emissions, Polar ecology.

\section{Abstract}

Measurements of alkylamines from seawater and atmospheric samples collected simultaneously across the Antarctic Peninsula, South Orkney and South Georgia Islands are reported. Concentrations of mono-, di- and trimethylamine (MMA, DMA and TMA, respectively), and their precursors, the quarternary amines glycine betaine and choline, were enhanced in sympagic sea water samples relative to ice-devoid pelagic ones, suggesting the microbiota of sea ice and sea ice-influenced ocean is a major source of these compounds. Primary sea-spray aerosol particles artificially generated by bubbling seawater samples were investigated by Aerosol Time-Of-Flight Mass Spectrometry (ATOFMS) of single particles; their mixing state indicated that alkylamines were aerosolized with sea spray from dissolved and particulate organic nitrogen pools. Despite this unequivocal sea spray-associated source of alkylamines, ATOFMS analyses of ambient aerosols in the sympagic region indicated that the majority (75-89 \%) of aerosol alkylamines were of secondary origin, i.e., incorporated into the aerosol after gaseous air-sea exchange. These findings show that sympagic seawater properties are a source of alkylamines influencing the biogenic aerosol fluxed from the ocean into the boundary layer; these organic nitrogen compounds should be considered when assessing secondary aerosol formation processes in Antarctica. 


\section{Introduction}

The impact of aerosols on cloud droplet concentrations and hence on cloud optical properties is of paramount importance for global climate ${ }^{1}$. Current climate models are particularly challenged in predicting the radiation budget, particularly the surface short wave radiation, over the Southern Ocean ${ }^{2}$. Overestimates of surface heating result in errors in predicted sea surface temperature (SST) and ocean heat uptake ${ }^{3}$, thus affecting long term climate predictions ${ }^{4}$.The source of such a bias is thought to be a poor representation of clouds along with the underprediction of the aerosol optical depth, which suggests a hitherto overlooked source of aerosols influencing cloud properties in this region ${ }^{5}$. In a pristine environment like Antarctica and its surrounding ocean, where the atmosphere still exists in its natural state ${ }^{6}$, missing aerosol sources from natural processes may be overlooked. Uncertainties for modeling aerosol-cloud interactions and cloud radiative forcing in part arise from a poor source apportionment of natural aerosols including emissions of biogenic sulfur and sea spray ${ }^{7}$. The relative roles of secondary aerosols produced from biogenic sulfur versus primary sea-spray aerosols in regulating cloudiness above the Southern Ocean remains controversial ${ }^{8-13}$. The plankton-derived trace gas dimethylsulfide (DMS) has long been identified as a major source of non-sea-salt sulfate and methanesulfonate in newly formed and aged secondary aerosols, enhancing particle number and mass concentrations $^{9}$. It is plausible that other organic aerosol components of biogenic origin may act similarly, contributing ingredients for aerosol formation and growth ${ }^{14}$. Moreover, there is growing evidence that sea spray does not only contribute sea salt particles to the aerosol pool, but organic matter with cloud-forming properties ${ }^{15}$. Despite the increasing awareness of their importance, measurements of organic components in Southern Ocean aerosols are even more scarce than inorganic measurements ${ }^{11,16,17}$. Recently, the first yearlong measurements of organic functional groups in coastal Antarctic aerosols showed a seasonal trend with 150 times higher natural organics in summer than in winter. These natural organics were mainly attributed to marine and seabird emissions ${ }^{18}$. 
The organic nitrogen $(\mathrm{ON})$ component of marine aerosols represents one of the largest unknowns in aerosol composition and behavior, mainly due to the complexity of the $\mathrm{ON}$ pool and a lack of highly time-resolved and/or coupled ocean and atmosphere measurements ${ }^{19,20}$. ON is considered a tracer species in Antarctica and has been studied through amino acid proxies in particles produced by bubble bursting at the air-sea interface ${ }^{21,22}$ and from the hatching of penguins ${ }^{23,24}$. A comprehensive characterization of marine sources of aerosol $\mathrm{ON}$ is hampered by the lack and difficulty of synergistic measurements in the surface ocean and atmosphere.

Recently, by means of synergistic atmospheric and oceanic measurements in the Southern Ocean near Antarctica, we reported that the microbiota of sea ice and sea ice-influenced ocean can be a source of atmospheric ON, specifically low molecular weight alkyl-amines and nitrogencontaining osmolytes ${ }^{25}$. One of the conclusions of that work was that there is the need for going beyond the use of surface chlorophyll a data as the sole predictor of marine organic nitrogen emissions, since identified nitrogen compounds did not co-vary with total phytoplankton pigment ${ }^{25}$.

In this work, we advance the study of Dall'Osto et al. $(2017)^{25}$ by reporting a detailed analysis of single particle mass spectra. Alkylamines may comprise a small percentage of marine organic nitrogen but can effectively diffuse across the sea-air interface where they may affect the chemistry of the atmosphere, for example being one of the few semi-volatile compounds that reacts with sulfate and other acidic species in the atmosphere to form aerosol. For the first time, an aerosol time-of-flight mass spectrometer (ATOFMS) was deployed in Antarctica during more than 40 days, rendering the composition of single aerosols from ambient air as well as from a sea-spray generation chamber on board. Aerosol mass spectra were compared with measurements in surface seawater and melted sea ice, and were interrogated for the presence of alkylamines, their mixing state, and their primary or secondary origin. 


\section{Methodology}

The cruise. The PEGASO (Plankton-derived Emissions of trace Gases and Aerosols in the Southern Ocean) cruise was conducted on board de RV Hesperides in the regions of Antarctic Peninsula, South Orkney and South Georgia Islands from 2 January to 11 February 2015.

Hydrographic measurements and seawater sampling. Thermosalinograph SBE 21 SeaCAT was used to record seawater salinity and temperature. Shipboard Acoustic Doppler Current Profiler (SADCP) "Ocean Surveyor" at 75 khz was used to measure water current. Niskin bottles of the CTD rosette were used from a depth of $4 \mathrm{~m}$ to collect sea water samples.

Sea Ice samples. Three sea ice samples were collected from a zodiac boat (selected for their brownish color indicating colonization by algae) on three different points during the field study at the northern and southern edge of the South Orkney Islands. Once on board of the RV Hesperides (A-33), the sea ice samples were melted (adding about 1/5 volume of sea water collected at the ship location near sea ice), and the melted sea ice introduced into the aerosol generator tank.

Atmospheric ambient sampling. The on-line instruments deployed on this study were housed inside the bow of the ship, an ad-hoc designed inlet $(9 \mathrm{~m}$ in length and 1" outer diameter, with a $\mathrm{PM}_{2.5}$ cut-off at a flow rate of $5 \mathrm{~L} \mathrm{~min}^{-1}$, overall residence time about 40 seconds) was used to collect aeroosl via a laminar flow. Off-line parallel aerosol samples were taken on the ship upper deck by means of a multistage impactor (5-stages Berner impactor, type LPI80, Hauke). Ion chromatography used for the discussion of the $\mathrm{pH}$ and partitioning of amines (Table S1-S3) was used for the subsequent quantification of water soluble inorganic ions and low molecular weight alkylamines (methyl-, ethyl-, dimethyl-, diethyl- and trimethylamine) (Facchini et al., 2008).

ATOFMS. We used the ATOFMS (model 3800-100, TSI, Inc.) to collect bipolar mass spectra of individual aerosol particles ${ }^{26,27}$. The ATOFMS is a particularly good aerosol instrument for studying amines and organic nitrogen in general because the LDI laser wavelength $(266 \mathrm{~nm})$ ionizes them very 
efficiently ${ }^{28-30}$. ATOFMS single particle positive and negative mass spectra were imported into YAADA (Yet Another ATOFMS Data Analyzer) and singleparticle mass spectra were grouped with adaptive resonance theory neural network, ART-2 $\mathrm{a}^{31}$ (learning rate 0.05 , vigilance factor 0.85 , and 20 iterations). Further details of the parameters can be found elsewhere ${ }^{32}$.

Briefly, the ART-2a area matrix (AM) of a single particle mass spectra reppresents the average intensity for each $\mathrm{m} / \mathrm{z}$ for all particles within a group, reflecting the typical mass spectra of specific aerosol groups.

Aerosol generation tank experiments. Seven open ocean water and three sea ice melt water samples (10 in total) were recirculated into plunging jet to generate bubbles and aerosols. By means of a square glass tank of $10 \mathrm{I}$ (filled with 3 I of sea water or melted sea ice, air flow of 11 I min, described elsewhere ${ }^{33}$ ), sprayed bubble-bursting aerosol size and composition was monitored with an ATOFMS.

Aqueous MA concentrations. Seawater samples $(850 \mathrm{ml})$ were gravityfiltered through $47 \mathrm{~mm}$ GF/F filters into $1 \mathrm{~L}$ high density polyethylene (HDPE) bottles containing $\mathrm{HCl}\left(10 \mathrm{~mL}, 11.6 \mathrm{M}\right.$, stored at $4{ }^{\circ} \mathrm{C}$ until analysis), then saturated with $\mathrm{NaCl}$ and adjusted to $\mathrm{pH} 13.4$ with $\mathrm{NaOH}$. Methylamines (mono-, di- and trymethylamines) were extracted from the water sample by solid phase microextraction ${ }^{34}$, where polydimethylsiloxane/divinylbenzene fibre was exposed in the headspace above the water sample, for $2.5 \mathrm{~h}$ at 60 ${ }^{\circ} \mathrm{C}$. Methylamines were resolved and detected using a GC with NP detector, calibrations carried out using external matrix-matched standard solutions containing mono-, di- and trimethylamine (0.13-13.3 nM).

Aqueous quarternary amine concentrations. Seawater samples $(10 \mathrm{~mL})$ were gravity filtered through $47 \mathrm{~mm}$ GF/F filters. The filters were flash frozen in liquid nitrogen and stored at $-80^{\circ} \mathrm{C}$ until analysis. Nitrogen osmolytes (glycine betaine and choline) were extracted from filters in 12:5:1 methanol:chloroform:water spiked with internal standard ( $\left.d_{11} G B T\right)$, and analysed by Liquid Chromatography/ Mass Spectrometry (LC/MS) according to Beale and Airs, 2016. Calibration was performed before each analysis using a calibration curve of solutions containing glycine betaine, choline and 
internal standard. Check standards were also analysed after every 3 samples to check instrument response.

\section{Results}

\subsection{Water and melted sea ice measurements}

Fig. 1 shows the transit of the research vessel A-33 Hesperides (solid black line). The study region of this study is the Weddell / Scotia Sea, and the border between sea ice influence and ice-free waters was defined by the position of the Southern Boundary of the Antarctic Circumpolar Current (SBACC), situated around 60 ㅇ (dotted black lines ${ }^{25}$ ).

The nitrogen-containing osmolytes glycine betaine and choline were measured in particulates from surface seawater (mainly biota) collected at all stations in Fig. 1. Glycine betaine and choline are used as osmolytes by marine microbes ${ }^{35}$, but can also act as a $\mathrm{C}, \mathrm{N}$ or energy source for marine biota $^{36-37}$. They are also precursors of methylamines ${ }^{38}$, which are volatile components of the marine organic nitrogen pool. They are ubiquitous in marine systems, however little is known about their distribution, production and fate in sea waters. The average concentration of glycine betaine+choline in the ice-influenced region south of the SBACC was $97 \mathrm{nM}$, and the concentrations in this ice influenced region were significantly higher (Welch's $t$ test; $p=0.017$ ) than those observed north of the SBACC (average $=43 \mathrm{nM}$, Fig. 1.) The total methylated amine (monomethylamine + dimethylamine + trimethylamine) concentration was also higher south of the SBACC (Welch's $t$ test; $p=0.042$; average concentration $=6.06 \mathrm{nM}$ ) than north of the border (average concentration $=2.51 \mathrm{nM}$; Fig. 1). Total methylated amine concentrations were also measured in two of the three melted ice samples, being 6.49 and $10.84 \mathrm{nM}$, which were well above the average concentration for the ice-influenced water samples. Nitrogen osmolytes were not measured in ice samples. The melted sea ice measurements were carried out $24 \mathrm{~h}$ after bubbling, at least after water recirculation for ice melting; as there was no 
control on gas losses, it is very likely these measurements are underestimates, nevertheless still supporting the idea that sea ice is a source of these chemical compounds.

\subsection{Aerosol chamber experiments}

Mass spectra of particles generated by bubbling melted sea ice were compared with those produced by bubbling surface sea water. We already reported that ATOFMS single-particle information on the mixing state revealed that $21 \%$ of the sea ice-derived particles were an internal mixture of sea salt with organic nitrogen and carbon, versus only $5 \%$ in seawater spray ${ }^{25}$. Here, we expanded the analysis by running ART-2a on the combined seawater and melted sea ice aerosol chamber dataset (approximately 7,000 single particle mass spectra). Initially 277 clusters were found but many were merged following procedures explained elsewhere ${ }^{32}$. Briefly, some of the main ART-2a clusters were very similar to each other. The main differences were due to the peak area or to the noise level $\left.\right|^{32}$. For example, a problem encountered in the classification of different particle types arises from the miscalibration of some peaks (i.e. whilst the ATOFMS positive spectra are almost identical between two different classes, the negative one could only differ by a shifting of $\mathrm{m} / \mathrm{z} 1$ of spectra or few peaks). Although the reason for this miscalibration is unknown ${ }^{32}$, the issue was solved by merging the two different ART-2a clusters. Through this merge, the total number of clusters describing the complete primary aerosol chamber database was reduced to four that describe about $90 \%$ of the population of particles with both positive and negative spectra. The remaining $10 \%$ of the population with both positive and negative spectra were characterised by low-mass spectral resolution and having low overall signal/noise. The primary aerosol chamber ATOFMS measurements revealed unique organic nitrogen features in the mass spectra of individual particles, named "OC-CHN" (Organic Carbon - Amines), "OC-CHN-NaCl" (Organic Carbon - Amines - Sodium Chloride), "NaCl-OC-CHN" (Sodium Chloride Organic Carbon - Amines) and "Ca-OC-CHN" (Calcium - Organic Carbon Amines), altogether accounting for about $5-21 \%$ of the ATOFMS particles 
classified during aerosol chamber experiments (depending on the water type bubbled). The positive and negative ART-2a area matrices for the four particle types described, and the average size distributions (unscaled ATOFMS data $^{39}$ ) are shown in Fig.s 2 and S1, respectively.

All particles were internally mixed with $\mathrm{Na}(\mathrm{m} / \mathrm{z} 23), \mathrm{Mg}(\mathrm{m} / \mathrm{z} 24), \mathrm{K}(\mathrm{m} / \mathrm{z} 39)$ and $\mathrm{Cl}(\mathrm{m} / \mathrm{z} 35)$, consistent with the expectation that they were internally mixed with sea salt in sea spray. Peaks at $m / z-111$ and -129 were attributed to $\left[\mathrm{NaCl}_{2}\left(\mathrm{H}_{2} \mathrm{O}\right)\right]^{-}$and $\left[\mathrm{NaCl}_{2}\left(\mathrm{H}_{2} \mathrm{O}\right)_{2}\right]^{-}$, respectively ${ }^{40}$. The presence of water in pure sea-salt particles was confirmed by the presence of peaks at $m / z-16[0]^{-}$, $-17[\mathrm{OH}]^{-},-46\left[\mathrm{Na}_{2}\right]^{-}, 62\left[\mathrm{Na}_{2} \mathrm{O}\right]^{+}$, and $63\left[\mathrm{Na}_{2} \mathrm{OH}\right]^{+}$. The negative ion mass spectrum shows prominent peaks at $m / z-26[\mathrm{CN}]^{-}$and $m / z-42\left[\mathrm{CNO}^{-}\right.$, indicating that all particle types presented were internally mixed with organonitrogen species (Fig. 2). These major peaks were seen in all single particle mass spectra and are not further described. However, some of the particle types presented more distinct peaks, hence the naming of the four particle types .

- OC-CHN (Organic Carbon- Amines): Fig. 2a shows the ATOFMS mass spectra of a particle type called OC-CHN. Based on previous studies, the peak at $\mathrm{m} / \mathrm{z} 59\left(\left[\mathrm{~N}\left(\mathrm{CH}_{3}\right)_{3}\right]^{+}\right)$was attributed to trimethylamine $(\mathrm{TMA})^{28,29}$. With a tertiary-substituted $\mathrm{N}$ atom, TMA is the most basic of the methylated amines and plays an important role in atmospheric chemistry, yet its pathway towards aerosol is not clear. Rehbein et al. (2011) ${ }^{41}$ demonstrated that cloud/fog processing could enhance gasto-particle partitioning of TMA. TMA can also participate in the formation of secondary organic aerosol. Several studies have shown that gas-phase TMA could form non-salt organic aerosol products through reaction with oxidizing agents ${ }^{42}$. However, in this study, we detected TMA in primary-generated aerosol particles; furthermore, the analysis of water samples also revealed the presence of TMA, and compounds that could readily produce TMA (eg. glycine betaine). Other peaks associated with amines included $\mathrm{m} / \mathrm{z} 72,74$ and 86 . A common characteristic of the diethylamine (DEA) spectra is the presence of ion peaks at $\mathrm{m} / \mathrm{z} 70,72$, and $74^{28}$. Fragment ions at $\mathrm{m} / \mathrm{z} 86$ and 114 are associated with two or more alkylamines. The $m / z 86$ fragment ion may 
also be associated with triethylamine (TEA) and dipropylamine (DPA), but has also been identified with other alkylamines products (Angelino et al., 2001). This ATOFMS OC-CHN particle type also presents peaks at $m / z 27\left[\mathrm{C}_{2} \mathrm{H}_{3}\right]^{+}$and $m / z 43\left[\left(\mathrm{CH}_{3}\right) \mathrm{CO}\right]^{+}$usually associated with oxidized organic aerosol ${ }^{43}$. Finally, the unique presence of peaks at $\mathrm{m} / \mathrm{z}-45,-59$ and -71 are likely to be due to the formate $\left[\mathrm{CHO}_{2}\right]^{-}$, acetate $\left[\mathrm{C}_{2} \mathrm{H}_{3} \mathrm{O}_{2}\right]^{-}$and propionate $\left[\mathrm{C}_{3} \mathrm{H}_{5} \mathrm{O}_{2}\right]^{-}$ions, respectively ${ }^{30}$. In summary, particle type $\mathrm{OC}-\mathrm{CHN}$ was characerized by the highest amount of organic peaks both in the positive and negative mass spectra, and distributed in the smallest size bins at about $0.5 \mu \mathrm{m}$ (Fig. S1).

- OC-CHN-NaCl (Organic Carbon - Amines - Sodium Chloride): Fig. 2b shows the ATOFMS mass spectra of a particle type called OC-CHN$\mathrm{NaCl}$. Relative to the previous one, this type shows a presence of a peak at $m / z 81\left[\mathrm{Na}_{2} \mathrm{Cl}\right]$, usually considered as a marker for $\mathrm{NaCl}^{40}$. Peaks due to organic species were very minor in the negative spectra. By contrast, peaks at peak -79 and -80 can be seen, possibly due to $\left[\mathrm{PO}_{3}\right]^{-}$and $\left[\mathrm{SO}_{3}\right]^{-}$, respectively. Fig. $\mathrm{S} 1$ shows an average size distribution peaking at about $0.8 \mu \mathrm{m}$.

- $\mathrm{NaCl}-\mathrm{ON}-\mathrm{CHN}$ (Sodium Chloride - Organic Carbon - Amines): Fig. 2c shows the ATOFMS mass spectra of a particle type called $\mathrm{NaCl}-\mathrm{OC}$ $\mathrm{CHN}$. Major peaks can be seen for sea spray due to $\left[\mathrm{Na}_{2} \mathrm{Cl}\right]^{+}(\mathrm{m} / z 81$ and 83$)$, and $\left[\mathrm{NaCl}_{2}\right]^{-}(\mathrm{m} / \mathrm{z}-93,-95$ and -97$)$, respectively, in the positive and negative mass spectra. This was confirmed by the larger average size distributions (Fig. S1) where supermicron particles were present.

- Ca-OC-CHN (Calcium - Organic Carbon - Amines): Fig. 2d shows the ATOFMS mass spectra of a particle type called $\mathrm{Ca}-\mathrm{OC}-\mathrm{CHN}$. This particle type showed very different average mass spectra both in the positive and negative mass mode. In the positive spectra, strong peaks associated with calcium $\left(\mathrm{m} / \mathrm{z} 40[\mathrm{Ca}]^{+}, 56[\mathrm{CaO}]^{+}, 57[\mathrm{CaOH}]^{+}\right.$and 96 $\left.\left[\mathrm{Ca}_{2} \mathrm{O}\right]^{+}\right)$were present. Peaks associated with sodium $(\mathrm{m} / \mathrm{z} 23)$, magnesium $(m / z 24,25)$ and potassium $(m / z 39)$ could also be seen. 
These particles were, on average, the largest submicron organic nitrogen-containing particles detected in this study (Fig. S1).

The ATOFMS single particle mass spectra collected during the primary aerosol chamber experiments revealed that all the amine-containing particles were internally mixed with sea spray, although larger supermicron particles showed stronger influence of sea spray and likely other Ca-rich components. The enrichment of calcium may be possibly related to marine polymeric gels, which are produced by phytoplankton and sea ice alga secretions and can be transferred by bubble bursting from the sea-air interface into the polar atmosphere ${ }^{44,45}$.These biopolymers are inter-bridged with divalent cations $\left(\mathrm{Ca}^{2+}\right.$ and $\left.\mathrm{Mg}^{2+}\right)$ to which other organic compounds, such as proteins and lipids, are readily bound, resulting in a gel-like consistency ${ }^{46}$.

\subsection{Aerosol ambient data}

The deployment of single-particle mass spectrometers already proved useful in the identification of alkylamines in ambient aerosol in real time, and have also enabled investigation of their mixing state ${ }^{29}$. Alkylamines have been detected in ambient air using single-particle mass spectrometers in a variety of locations, including the continental USA ${ }^{47}$, Canada $^{41}$, China ${ }^{48,49}$, Mexico ${ }^{50}$ and Europe ${ }^{29}$. It is interesting to note that in a marine location in Corsica (France), all alkylamines detected in particles were also found to be internally mixed with methanesulfonic acid, indicating that aminium methanesulfonate salts may represent a component of marine ambient aerosol in the summer months ${ }^{29}$. In remote marine conditions, Dall'Osto et al. (2012) ${ }^{51}$ reported nitrogenated and aliphatic organic vapors as possible drivers for marine secondary organic aerosol growth. Recently, Kollner et al (2017) ${ }^{52}$ reported that a significant fraction (23\%) of the single particles sampled in the Canadian high Arctic lower troposphere contained trimethylamine originating from marine biogenic emissions.

Our ATOFMS mass spectra of ambient aerosols in the areas of the Antarctic Peninsula, South Orkney and South Georgia Islands revealed that 
alkylamines were present in about a quarter of the particles containing organic species. We then associated ATOFMS mass spectra with different air mass trajectory histories, specifically "open water" (OW) and "sea-ice" (SI) source regions, according to the characteristics of the area overflown ${ }^{25}$. The results are shown in Fig. 3: ice-influenced air masses showed a strong enhancement of $\mathrm{ON}$-containing peaks relative to those from the open ocean. When the $\mathrm{ON}$ containing ATOFMS spectra were interrogated for the presence of sea salt, only 11-25\% corresponded, suggesting most of the amines were of secondary origin. The non-negligible \% of sea salt, however, also suggests the contribution of primary $\mathrm{N}$-containing aerosol carried by sea spray. The action of wind friction on the surface ocean generates air bubbles that scavenge colloidal and particulate organic matter, including proteinaceous gels, bacteria and viruses, and release them into the atmosphere by bursting ${ }^{21,22}$. It is worth noting that the majority of the ambient ATOFMS spectra contained a main peak at $m / z$ 114, which may be assigned to dipropylamine or tripropylamine ${ }^{28,29}$. This peak was not seen in ATOFMS positive mass spectra from the generated primary aerosols reported (Fig. 2). The marker ion at $m / z 114$ has previously been demonstrated to be preserved in particles that contain amine salts and which have been subjected to photooxidation $^{29,30}$. Further studies are needed to understand more about the origin of the peak at $\mathrm{m} / \mathrm{z} 114$ and why it was not seen in aerosol tank experiments. It is likely that unknown photo-oxidative processes could be converting ON primary species into the ambient atmosphere ones responsible for the peak at $\mathrm{m} / \mathrm{z} 114$. An example of a single particle mass spectrum collected in the open ocean ambient air is shown in Fig. S2. Air mass back trajectories ${ }^{25}$ showed that this aerosol travelled mainly over open pack sea ice (77 \% of the time), over open sea (23\%) and never over land. Peaks at $m / z 59,74$ and 114 (alkylamines peaks of $\left[\left(\mathrm{CH}_{3}\right)_{3} \mathrm{~N}\right]^{+}, \quad\left[\left(\mathrm{C}_{2} \mathrm{H}_{5}\right)_{2} \mathrm{NH}_{2}\right]^{+}, \quad\left[\left(\mathrm{C}_{3} \mathrm{H}_{7}\right)_{2} \mathrm{NCH}_{2}\right]^{+}$, respectively ${ }^{28}$ ) dominated the positive mass spectra. In the negative mass spectra, peaks due to oxalate $\left(\mathrm{m} / \mathrm{z}-89,\left[\left(\mathrm{C}_{2} \mathrm{O}_{4} \mathrm{H}\right) \mathrm{H}\right]^{-}\right)$and to a lesser extent sulfate $\left(m / z-97\left[\mathrm{SO}_{4}\right]^{2-}\right)$ could be seen. The small peak at $\mathrm{m} / z \quad 179$ is attributed to the oxalic acid dimer $\left[\left(\mathrm{C}_{2} \mathrm{O}_{4} \mathrm{H}\right)_{2} \mathrm{H}\right]^{-}$, which is commonly observed in the spectra of oxalic acid standards. This supports the fact that the peak at $m / z-89$ can be predominantly attributed to oxalic acid ${ }^{53}$. Other peaks at high 
$\mathrm{m} / \mathrm{z}$ in both positive and negative mass spectra could not be identified. The minor presence of inorganic peaks suggests that this particle type had a high degree of organic material, likely formed via secondary processes.

\section{Discussion and conclusion}

\section{Ocean water-melted sea ice measurements and aerosol generation tank}

experiments. Here, we have provided data showing that ice-influenced surface waters are enriched in alkylamines and their precursors, the algal osmolytes glycine betaine and choline (Fig. 1). In the current study - by a complete analysis of single particle mass spectra from bubbling tank experiments with melted sea ice, ice-influenced and non-ice-influenced sea waters - demonstrates that the sympagic environment (i.e., sea ice and sea ice-influenced sea waters) is more likely to supply alkylamines in sprayed aerosols than open ocean pelagic water. Single particle mass spectrometry helps determine how different chemical constituents are distributed among particles (namely, the mixing state). The aerosol mixing state in turn can affect droplet formation when the resulting hygroscopicity distribution is sufficiently heterogeneous ${ }^{54}$. The mass spectra of an aerosol population can be defined as the degree of homogeneity in the distribution of the chemical components within it ${ }^{55}$. Thus, an aerosol population can be broadly defined as "internally mixed" when each single particle presents the same chemical composition, which equals the bulk composition), or "externally mixed" when particles of different chemical composition co-occur. All the generated primary aerosols were internally mixed with sea salt within the detectable ATOFMS size range (about 350-1350 nm). Both DMA and TMA were identified in the mass spectra of these internally mixed aerosols (Fig. 2a-d), suggesting that the alkylamines were part of the dissolved organic matter sprayed by bubble bursting. A subset of coarser particles contained alkylamines internally mixed with calcium, which could originate from algae or other biological samples in the form of particulate organic matter such as marine polymeric gels (Fig. 2d). 
Atmospheric ambient sampling. In the clean, marine Antarctic atmosphere, the particle number concentration of primary and secondary aerosols is mainly driven by the seasonality of biological productivity in the Southern Ocean ${ }^{16-17}$, 56-59. The mechanisms, however, for the production of either primary or secondary biogenic aerosols are not fully clarified. In our ambient aerosols study, about a fourth of the detected and analyzed particles collected in Antarctic air masses over a period of about 40 days contained alkylamines. Most of them (75-89\%), were externally mixed with sea spray and likely were of secondary origin.

Based on the effective Henry's law Constant $\left(\mathrm{K}_{\mathrm{H}}\right)$ of TMA at $278 \mathrm{~K}$, reported by Leng et al. $(2015)^{60}$, and on the observed concentrations of TMA in seawater (4.2 nM), we estimate an equilibrium gas phase concentration of $110 \mathrm{pmol} \mathrm{m}^{-3}$ over the sea-ice influenced zone. The concentrations of $\mathrm{TMA}^{+}$ determined in the aerosol phase were $13.5 \mathrm{pmol} \mathrm{m}^{-3}$, about one order of magnitude lower than those estimated in the gas phase. TMA (and other lowmolecular weight alkylamines as well) is water-soluble and semi-volatile, so it tends to partition between the gas and aerosol phase as dictated by equilibrium thermodynamics. Similar to its inorganic counterpart ammonia/ammonium, TMA tends to increasingly partition to the aerosol as temperature decreases, and, aerosol LWC \& acidity increases. Antarctic aerosol, owing to its low dry aerosol loading, tends to have low aerosol concentration (hence LWC); nevertheless, a significant fraction of alkylamines may still reside in the aerosol, if it is acidic enough ${ }^{60}$. To demonstrate this, we apply the gas-particle partitioning equation by Leng et al. (2015), based on a $\mathrm{pH}$-dependent formulation of the $\mathrm{K}_{\mathrm{H}}$. Aerosol liquid water content (LWC) and $\mathrm{pH}$ were calculated by the ISORROPIA-II model ${ }^{61,62}$ using the chemical composition of ambient aerosol already described in Dall'Osto et al. $(2017)^{25}$, the ambient air Temperature (T) and Relative Humidity (RH) measured during the cruise (see Table S1-S3). Aerosol LWC and pH resulted in average values of $0.65 \mu \mathrm{g} \mathrm{m}^{-3}$ and 1.4 , respectively, over the sea-ice influence zone. Under such conditions, a transfer of $13 \%$ of TMA is expected to partition in the particle phase. These calculations demonstrate that the concentrations of alkyl-amines measured in the ambient aerosol and in the surface ocean waters are consistent with equilibrium partitioning theory. They 
also demonstrate that a flux of low molecular weight alkyl amines from seawater to the atmospheric gas phase and subsequent condensation onto acidic sub-micron particles is possible over the Weddell Sea - and in fact will only partition to the most acidic of submicron particles (ultrafines). The presence of TMA also further supports the thought that marine aerosol is strongly acidic, which in itself carries important implications for the processes that determine the bioavailbility of trace nutrients and metals in submicron aerosol.

Organic nitrogen sources in the Antarctic region. Little is currently known of the role of the atmosphere in redistributing nitrogen species across marine ecosystems. Dall'Osto et al. (2017) ${ }^{25}$ reported ambient aerosol concentrations of sub-micrometer low molecular weight amines, of $7.1( \pm 1.8)$ and $1.5( \pm 0.8)$ $\mathrm{ng} \mathrm{m}^{-3}$ for the "sea-ice" and "open-water" source regions, respectively, during the cruise object of the present study. The total amine concentration resulted from five detected species, namely methylamine $\left(M A_{+}\right)$, ethylamine $\left(E A_{+}\right)$, dimethylamine $(\mathrm{DMA}+)$, diethylamine $(\mathrm{DEA}+)$ and trimethylamine $(\mathrm{TMA}+)$, with $D M A+$ and $D E A+$ being the most abundant in both regimes. The DMA+ concentration reported for the "sea-ice" region $\left(2.0 \pm 0.4 \mathrm{ng} \mathrm{m}^{-3}\right)$ is comparable to those reported by Gibbs et al. (1999) ${ }^{63}$ for the Arabian sea (August-October 1994) but lower (from 5 to 60 times) than the values reported for the North Atlantic ocean, during the high biological activity period ${ }^{19}$, and for the marginal seas of China ${ }^{64,65}$. Lower concentrations (about one order of magnitude) than those observed over the Weddell Sea were reported by Müller et al. (2009) ${ }^{66}$ at Cape Verde (tropical Atlantic waters). Similarly, $\mathrm{DEA}^{+}$concentration $\left(3.8 \pm 1.0 \mathrm{ng} \mathrm{m}^{-3}\right)$ over the Weddell Sea is lower than mid-latitude North Atlantic ocean concentrations ${ }^{19}$ and higher than Tropical Atlantic ocean ones ${ }^{66}$. Literature data for $\mathrm{TMA}^{+}$concentration in the marine environment are available for the Arabian Sea ${ }^{63}$ and for the marginal seas of China ${ }^{65,66}$, with the latter having almost three orders of magnitude higher concentrations than the former; the average concentration of $\mathrm{TMA}^{+}$observed over the Weddell Sea $\left(0.8 \pm 0.3 \mathrm{ng} \mathrm{m}^{-3}\right)$ falls within the range of the previous observations. The average alkylamines $/ \mathrm{NH}^{+}$molar ratios observed in the "sea-ice" and "open 
sea" source regions were 0.03 and 0.02 , respectively, falling in the range of literature reported values.

The pioneering study of Legrand and Ducroz (1998) ${ }^{67}$ discussed the influence of polar ocean and penguin emissions on ammonium concentrations in coastal Antarctica. Atmospheric ammonium concentrations were quite variable, with a summer maximum ranging from 12.5 to $140-260 \mathrm{ng} \mathrm{m}^{-3}$. The emissions from the penguin population would not seem to be a major source, yet ammonia emission all over Antarctica was considered uncertain. Aerosol produced by ornithogenic soil emissions may contain oxalate, which may be produced together with ammonium by bacterial decomposition of uric acid. This may permits the subsequent loss of ammonia - and likely other volatile organic nitrogen compounds - to the atmosphere ${ }^{23,67,68}$. As mentioned earlier, a "marine" and a "seabird" source were also identified in the southern tip of Ross Island ${ }^{18}$. The marine source was identified by its high hydroxyl group fraction, and the seabird source by its fingerprints of ammonium and organic nitrogen, they constituted the main sources of $\mathrm{CCN}$ in the remote marine boundary layer. During our study, alkylamines detected in ambient air were associated with air masses that had previously travelled over the ice-covered Weddell Sea and its marginal zone of ice-influenced ocean, along with some spots around the Antarctic Peninsula and the South Georgia phytoplankton bloom $^{25}$, excluding coastal penguin emissions. Given that our study was carried out in open ocean regions, it is not surprising that there was little influence from coastal penguin emissions. Further studies are needed to apportion the relative importance of bird colonies and sympagic/pelagic open ocean water. We found that some alkylamines of secondary origin were associated with oxalic acid (Fig. S2). Since oxalate is generally thought to arise from aqueous phase oxidation, future work will address the sources of oxalic acid and its mixing state in the Antarctic atmosphere.

In the marine environment, low molecular weight aliphatic amines usually have gas-phase concentrations that are about two orders of magnitude lower than that of ammonia $\left(\mathrm{NH}_{3}\right)$; however, these species are more basic than $\mathrm{NH}_{3}$, which makes them better suited to neutralize strong acids like sulfuric and methanesulfonic and stabilize molecular clusters that may lead to new particle formation ${ }^{69}$. Currently, very little is known about the 
relative gas phase concentrations of ammonia and amines in the Antarctic regions, such measurements would be highly valuable. Almeida et al. $(2013)^{70}$ demonstrated that atmospheric concentrations of DMA could enhance particle-formation more than 1,000-fold compared with ammonia, enough to account for the observed atmospheric particle-formation rates. Hence, given the low particle number concentrations reported in Antarctic regions ${ }^{71,72}$, alkylamines could play a role in particle formation by nucleation. Further studies, with instruments capable of resolving the composition of molecular clusters $^{73}$, are needed to confirm or reject this suggestion.

Very few studies have measured the chemical composition of aerosols in the summertime Antarctic. Here we should that (a) high concentrations of alkylamines can be found in melted sea ice and sea-ice-influenced waters; (b) they could result from degradation of quaternary amine osmolytes, which we also found in sympagic plankton; (c) sea-spray generation experiments showed that alkylamines were internally mixed with sea salt, hence they are carried by sea spray into primary aerosols; (d) in ambient air, they were mostly externally mixed with sea salt and hence, of secondary origin; (e) thermodynamic equilibrium calculations suggest their shift from primary to secondary aerosol tends is driven by the large $\mathrm{pH}$ gradient seen between fine and ultrafine particles; (f) air mass back trajectory analysis exclude a major association with bird emissions. Our study points to sea ice and surrounding microbiota being an important and overlooked contributor to aerosols through emissions of volatile and non volatile organic nitrogen, including alkylamines. Further data in these undersampled remote oceanic regions - both from mobile and fixed platforms - are needed in order to correctly apportion the role of sympagic and pelagic waters, seabirds and mammals as atmospheric nitrogen sources in the Antarctic and Southern Ocean atmosphere. Understanding how alkylamines interact to form aerosols, may be one of the important missing pieces to accurately forecast aerosol production around Antarctica, including possibly how re-evaporation of amines from the aerosol phase may help promoting new particle formation. 


\section{Acknowledgements}

The study was supported by the Spanish Ministry of Economy through project BIOeNUC (CGL2013-49020-R), PI-ICE (CTM2017-89117-R) and the Ramon y Cajal fellowship (RYC-2012-11922), and by the EU though the FP7PEOPLE-2013-IOF programme (Project number 624680, MANU - Marine Aerosol NUcleations), all to MD, and PEGASO (CTM2012-37615) to RS. We wish to thank the Spanish Armada, and particularly the captains and crew of the BIO A-33 Hesperides, for their invaluable collaboration. We are also indebted to the UTM, and especially Miki Ojeda, for logistic and technical support. The Spanish Antarctic Programme and Polar Committee provided context and advice. The National Centre for Atmospheric Science NCAS Birmingham group is funded by the UK Natural Environment Research Council. We would like to thank Dr. K. Sellegri (LaMP/CNRS, France) for lending a small sea spray tank for lab studies. The whole PEGASO team is also acknowledged.

\section{References}

(1) Seinfeld, J. H., Bretherton, C., Carslaw, K. S., Coe, H., De-Mott, P. J., Dunlea, E. J., Feingold, G., Ghan, S., Guenther,A. B., Kahn, R., Kraucunas, I., Kreidenweis, S. M., Molina,M. J., Nenes, A., Penner, J. E., Prather, K. A., Ramanathan,V., Ramaswamy, V., Rasch, P. J., Ravishankara, A. R., Rosenfeld,D., Stephens, G., and Wood, R, Improving our fundamental understanding of the role of aerosol-cloud interactions inthe climate system, $\underline{P}$ Natl. Acad. Sci. USA, 2016, 113, 5781-5790, https://doi.org/10.1073/pnas.1514043113.

(2) Bodas-Salcedo, A., K. D. Williams, P. R. Field, and A. P. Lock, The surface downwelling solar radiation surplus over the Southern Ocean in the Met Office model: The role of midlatitude cyclone clouds. J. Climate, 2012, 25, 7467-7486, doi:10.1175/JCLI-D-11-00702.1.

(3) Frolicher, T.L., Sarmiento, J.L., Paynter, D.J., Dunne, J.P., Krasting, J.P., Winton, M., Dominance of the Southern Ocean in anthropogenic carbon and heat uptake in CMIP5 models. J. Clim., 2015, 28, 862-886. http://dx.doi.org/10.1175/JCLI-D-14-00117.1.

(4) Kay J. E., L. Bourdages, N. B. Miller, A. Morrison, V. Yettella, H. Chepfer, and B. Eaton, Evaluating and improving cloud phase in the Community Atmosphere Model version 5 using spaceborne lidar observations. J. Geophys. Res. Atmos., 2016, 121, 4162-4176, doi:10.1002/2015JD024699.

(5) Humphries, R. S., Klekociuk, A. R., Schofield, R., Keywood, M., Ward, J., and Wilson, S. R., Unexpectedly high ultrafine aerosol 
concentrations above East Antarctic sea ice, Atmos. Chem. Phys.,2016, 16, 2185-2206, https://doi.org/10.5194/acp- 16-2185-2016

(6) Hamilton, D. S., Lee, L. A., Pringle, K. J., Reddington, C. L., Spracklen, D. V., and Carslaw, K. S., Occurrence of pristine aerosol environments on a polluted planet, P. Natl. Acad. Sci. USA, 2014, 111, 18466-18471.

(7) Carslaw, K.S., Lee, L.A., Reddington, C.L., Pringle, K.J., Rap, A., Forster, P.M., Mann, G.W., Spracklen, D.V., Woodhouse, M.T., Regayre, L.A., Pierce, J.R., Large contribution of natural aerosols to uncertainty in indirect forcing. Nature, 2013, 503, 67-71. https://doi.org/10.1038/nature12674

(8) Meskhidze,N, A. Nenes, Phytoplankton and cloudiness in the Southern Ocean. Science, 2006, 314, 1419-1423.

(9) Korhonen, H, K. S. Carslaw, D. V. Spracklen, G. W. Mann, M. T. Woodhouse, Influence of oceanic dimethyl sulfide emissions on cloud condensation nuclei concentrations and seasonality over the remote Southern Hemisphere oceans: A global model study. J. Geophys. Res. Atmos., 2008, 113, D15204.

(10) Quinn, P. K., and T. S. Bates, The case against climate regulation via oceanic phytoplankton sulphur emissions, Nature, 2011, 480(7375), 51-56, doi:10.1038/nature10580

(11) McCoy, D.T., Burrows, S.M.,Wood, R., Grosvenor, D.P., Elliott, S.M.,Ma, P., ... Hartmann, D.L., Natural aerosols explain seasonal and spatial patterns of Southern Ocean cloud albedo. Science Advances, 2015, 1, e1500157.

(12) Gras, J. L. and Keywood, M., Cloud condensation nuclei over the Southern Ocean: wind dependence and seasonal cycles, Atmos. Chem. Phys., 2017, 4419-4432, https://doi.org/10.5194/acp-17-4419-2017.

(13) Fossum, K. N., Ovadnevaite J., Ceburnis D., Dall'Osto M., Marullo S., Bellacicco M., Simó R., Liu D., Flynn M., Zuend A. and O'Dowd C., Summertime Primary and Secondary Contributions to Southern Ocean Cloud Condensation Nuclei. Scientific Reports, 2018, volume 8, Article number: 13844

(14) Brooks, S. D. and Thornton, D. C. O., Marine Aerosols and Clouds, Annu. Rev. Mar. Sci., 2018, 10, 289-313.

(15) O'Dowd, C. D. \& de Leeuw, G., Marine aerosol production: a review of the current knowledge. Philosophical Transactions of the RoyalSociety A: Mathematical, Physical and Engineering Sciences, 2007, 365, 1753.

(16) Legrand, M., Preunkert, S., Weller, R., Zipf, L., Elsässer, C., Merchel, S., Rugel, G., and Wagenbach, D., Year-round record of bulk and size-segregated aerosol composition in central Antarctica (Concordia site) Part 2: Biogenic sulfur (sulfate and methanesulfonate) aerosol, Atmos. Chem. Phys., 2017, 17, 14055- 14073, https://doi.org/10.5194/acp-17-14055-2017

(17) Legrand, M., Preunkert, S., Wolff, E., Weller, R., Jourdain, B., and Wagenbach, D., Year-round records of bulk and sizesegregated erosol composition in central Antarctica (Concordia site) - Part 1: Fractionation of sea-salt particles, Atmos. Chem. Phys., 2017, 17, 14039-14054, https://doi.org/10.5194/acp-17-14039- 2017.

(18) Liu, J., Dedrick, J., Russell, L. M., Senum, G. I., Uin, J., Kuang, C., Springston, S. R., Leaitch, W. R., Aiken, A. C., and Lubin, D., High 
summertime aerosol organic functional group concentrations from marine and seabird sources at Ross Island, Antarctica, during AWARE, Atmos. Chem. Phys., 2018, 18, 8571-8587, https://doi.org/10.5194/acp-18-8571-2018.

(19) Facchini,M.C., Decesari, S., Rinaldi, M., Carbone, C., Finessi, E., Mircea, M., Fuzzi, S.,Moretti,F., Tagliavini, E., Ceburnis, D., O'Dowd, C.D., Important source of marine secondary organic aerosol from biogenic amines. Environ. Sci. Technol., 2008, 42, 9116-9121

(20) Altieri, K. E., S. E. Fawcett, A. J. Peters, D. M. Sigman, and M. G. Hastings, Marine biogenic source of atmospheric organic nitrogen in the subtropical North Atlantic, Proc. Natl. Acad. Sci. U. S. A. , 2016, 113 (4), 925930. https://doi.org/10.1073/pnas.1516847113

(21) Barbaro E, Zangrando R, Vecchiato M, Piazza R, Cairns WRL, Capodaglio G, Barbante C, Gambaro A., Free amino acids in Antarctic aerosol: potential markers for the evolution and fate of marine aerosol. Atmos Chem Phys, 2015, 15:5457-5469

(22) Scalabrin, E., Zangrando, R., Barbaro, E., Kehrwald, N. M., Gabrieli, J., Barbante, C., and Gambaro, A., Amino acids in Arctic aerosols, Atmos. Chem. Phys., 2012, 12, 10453-10463, doi:10.5194/acp-12-104532012.

(23) Legrand, M., Gros, V., Preunkert, S., Sarda-Esteve, R., Thierry, A. M., Pepy, G., and Jourdain, B., A reassessment of the budget of formic and acetic acids in the boundary layer at Dumont d'Urville (coastal Antarctica): The role of penguin emissions on the budget of several oxygenated volatile organic compounds, J. Geophys. Res.-Atmos., 2012, 117, D06308, https://doi.org/10.1029/2011jd017102.

(24) Schmale, J., Schneider, J., Nemitz, E., Tang, Y. S., Dragosits, U., Blackall, T. D., Trathan, P. N., Phillips, G. J., Sutton, M., and Braban, C. F., Sub-Antarctic marine aerosol: dominant contributions from biogenic sources, Atmos. Chem. Phys., 2013, 13, 8669-8694, https://doi.org/10.5194/acp-138669-2013.

(25) Dall'Osto, M., Ovadnevaite, J., Paglione, M., Beddows, D.C.S., Ceburnis, D., Cree, C., Cortés, P., Zamanillo, M., Nunes, S.O., Pérez, G.L., Ortega-Retuerta, E., Emelianov, M., Vaqué, D., Marrasé, C., Estrada, M., Montserrat Sala, M., Vidal, M., Fitzsimons, M.F., Beale, R., Airs, R., Rinaldi, M., Decesari, S., Facchini, M.C., Harrison, R.M., O'Dowd, C., Simó, R., Antarctic sea ice region as a source of biogenic organic nitrogen in aerosols. Sci. Rep. 2017, 7 6047. https://doi.org/10.1038/s41598-017-06188-x.

(26) Laskin, A., Laskin, J., and Nizkorodov, S. A., Mass spectrometric approaches for chemical characterization of atmospheric aerosols: critical review of the most recent advances, Environ. Chem., 2012, 9, 163-189

(27) Gard, E., Mayer, J. E., Morrical, B. D., Dienes, T., Fergenson, D. P., and Prather, K. A., Real-time analysis of individual atmospheric aerosol particles: Design and performance of a portable ATOFMS, Anal. Chem., 1997, 69, 4083-4091.

(28) Angelino, S., Suess, D. T., and Prather, K. A., Formation of aerosol particles from reactions of secondary and tertiary alkylamines: Characterization by aerosol time-of-flight mass spectrometry, Environ. Sci. Technol., 2001, 35, 3130-3138.

(29) Healy, R.M., Evans, G.J., Murphy, M., Sierau, B., Arndt, J., McGillicuddy, E., O'Connor, I.P., Sodeau, J.R., Wenger, J.C., Single-particle 
speciation of alkylamines in ambient aerosol at five European sites. Anal. Bioanal. Chem. 2015, 407, 5899-5909

(30) Dall'Osto, M., Beddows, D. C. S., McGillicuddy, E. J., EsserGietl, J. K., Harrison, R. M., and Wenger, J. C., On the simultaneous deployment of two single-particle mass spectrometers at an urban background and a roadside site during SAPUSS, Atmos. Chem. Phys., 2016, 16, 9693-9710, https://doi.org/10.5194/acp-16-9693-2016.

(31) Song, X. H., Hopke, P. K., Fergenson, D. P., and Prather, K. A., Classification of single particles analyzed by ATOFMS using an artificial neural network, ART-2A, Anal. Chem., 1999, 71, 860-865

(32) Dall'Osto, M. and Harrison R. M., Chemical Characterisation of single airborne particles in Athens (Greece) by ATOFMS, Atmos. Environ., 2006, 40, 7614-7631.

(33) Schwier, A. N. et al., Primary marine aerosol emissions from the Mediterranean Sea during pre-bloom and oligotrophic conditions:

correlations to seawater chlorophyll a from a mesocosm study. Atmos. Chem. Phys. 2015, 15, 7961-7976.

(34) Cree Charlotte H.L., Airs Ruth, Archer Stephen D., Fitzsimons Mark F. Measurement of methylamines in seawater using solid phase microextraction and gas chromatography. Limnology \& Oceanography: Methods 2018, 16, 411-420. doi: 10.1002/lom3.10255

(35) Burg, M.B. Ferraris J.D., Intracellular organic osmolytes: function and regulation, J. Biol. Chem. 2008, 283 ,7309-7313

(36) Lidbury, I., J. C. Murrell, and Y. Chen, Trimethylamine and trimethylamine $\mathrm{N}$-oxide are supplementary energy sources for a marine heterotrophic bacterium: implications for marine carbon and nitrogen cycling. Isme Journal 2015, 9: 760-769.

(37) Lidbury, I. et al., A mechanism for bacterial transformation of dimethylsulfide to dimethylsulfoxide: a missing link in the marine organic sulfur cycle. Environmental Microbiology 201618: 2754-2766.

(38) Jameson, E., A. C. Doxey, R. Airs, K. J. Purdy, J. C. Murrell, and Y. Chen, Metagenomic data-mining reveals contrasting microbial populations responsible for trimethylamine formation in human gut and marine ecosystems. Microbial Genomics 2016, 2: doi: 10.1099/mgen.0.000080.

(40) Dall'Osto, M., Beddows, D.C.S., Kinnersley, R.P., Harrison, R.M., Donovan, R.J., Heal, M.R., Characterization of individual airborne particles by using Aerosol Time-of-Flight Mass Spectrometry (ATOFMS) at Mace Head, Ireland. Journal of Geophysical Research 2004, 109, D21302. doi:10.1029/2004/JD004747

(41) Rehbein PJG, Jeong C-H, McGuire ML, Yao X, Corbin JC, Evans G.J., Cloud and fog processing enhanced gas-to-particle partitioning of trimethylamine. Environ Sci Technol, 2011, 45(10):4346- 4352. doi:10.1021/es1042113

(42) Murphy S.M., Sorooshian A., Kroll J.H., Ng N.L., Chhabra P., Tong C., Surratt J.D., Knipping E., Flagan R.C., Seinfeld J.H., Secondary aerosol formation from atmospheric reactions of aliphatic amines. Atmos. Chem. Phys. 2007, 7(9):2313-2337

(43) Sullivan, R. C. and Prather, K. A.. Recent advances in our understanding of atmospheric chemistry and climate made possible by on-line aerosol analysis instrumentation, Anal. Chem. 2005, 77, 3861- 3886. 
(44) Leck, C. and Bigg, E. K. Evolution of the marine aerosol - a new perspective. Geophys. Res. Lett., 2005, 32, L19803, doi:10.1029/2005GL023651.

(45) Orellana, M. V. et al., Marine microgels as a source of cloud condensation nuclei in the high Arctic. Proc. Natl. Acad. Sci. 2011, 108(33), 13612-13617.

(46) Verdugo, P.A.. Marine microgels. Annual Review of Marine Science 2012, 4, 375-400.

(47) Pratt K.A., Hatch L.E., Prather K.A., Seasonal volatility dependence of ambient particle phase amines. Environ Sci Technol 2009, 43(14): 5276-5281. doi:10.1021/es803189n

(48) Zhang G., Bi X., Chan L.Y., Li L., Wang X., Feng J., Sheng G., Fu J., Li M., Zhou Z., Enhanced trimethylamine-containing particles during fog events detected by single particle aerosol mass spectrometry in urban Guangzhou, China. Atmos Environ. 2012, 55:121-126. doi:10.1016/j.atmosenv.2012.03.038

(49) Cheng, C., Huang, Z., Chan, C. K., Chu, Y., Li, M., Zhang, T., Ou, Y., Chen, D., Cheng, P., Li, L., Gao, W., Huang, Z., Huang, B., Fu, Z., and Zhou, Z., Characteristics and mixing state of amine-containing particles at a rural site in the Pearl River Delta, China, Atmos. Chem. Phys., 2018, 18, 9147-9159, https://doi.org/10.5194/acp-18-9147-2018.

(50) Moffet R.C., de Foy B., Molina L.T., Molina M.J., Prather K.A., Measurement of ambient aerosols in northern Mexico City by single particle mass spectrometry. Atmos. Chem. Phys. 2008, 8(16):4499-4516

(51) Dall'Osto, M., Ceburnis, D., Monahan, C., Worsnop, D. R., Bialek,J., Kulmala, M., Kurtén, T., Ehn, M., Wenger, J., Sodeau,J., Healy, R., and O'Dowd, C., Nitrogenated and aliphaticorganic vapors as possible drivers for marine secondary organicaerosol growth, J. Geophys. Res.-Atmos., 2012, 117, D12311, doi:10.1029/2012JD017522.

(52) Köllner, F., Schneider, J., Willis, M. D., Klimach, T., Helleis, F., Bozem, H., Kunkel, D., Hoor, P., Burkart, J., Leaitch, W. R., Aliabadi, A. A., Abbatt, J. P. D., Herber, A. B., and Borrmann, S., Particulate trimethylamine in the summertime Canadian high Arctic lower troposphere, Atmos. Chem. Phys., 2017, 17, 13747-13766, https://doi.org/10.5194/acp-17-13747-2017.

(53) Sullivan, R. C. and Prather, K. A., Investigations of the diurnal cycle and mixing state of oxalic acid in individual particles in Asian aerosol outflow, Environ. Sci Technol., 2007, 41, 8062-8069.

(54) Wex, H., G. McFiggans, S. Henning, and F. Stratmann, Influence of the external mixing state of atmospheric aerosol on derived CCN number concent rations, Geophys. Res. Lett., 2010, 37, L10805, doi:10.1029/2010GL043337

(55) Dall'Osto, M., Harrison, R.M., Highwood, E.J., O'Dowd, C., Ceburnis, D., Querol, X., Achterberg, E.P., Variation of the mixing state of Saharan dust particles with atmospheric transport. Atmos. Environ. 2010, 44, $3135 \mathrm{e} 3146$.

(56) Giordano, M. R., Kalnajs, L. E., Avery, A., Goetz, J. D., Davis, S. M., and DeCarlo, P. F.: A missing source of aerosols in Antarctica - beyond long-range transport, phytoplankton, and photochemistry, Atmos. Chem. Phys., 17, 1-20, https://doi.org/10.5194/acp-17-1-2017, 2017. 
(57) Giordano, M. R., Kalnajs, L. E., Goetz, J. D., Avery, A. M., Katz, E., May, N. W., Leemon, A., Mattson, C., Pratt, K. A., and DeCarlo, P. F.: The importance of blowing snow to halogen-containing aerosol in coastal Antarctica: influence of source region versus wind speed, Atmos. Chem. Phys., 18, 16689-16711, https://doi.org/10.5194/acp-18-16689-2018, 2018.

(58) Humphries, R. S., Schofield, R., Keywood, M. D., Ward, J., Pierce, J. R., Gionfriddo, C. M., Tate, M. T., Krabbenhoft, D. P., Galbally, I. E., Molloy, S. B., Klekociuk, A. R., Johnston, P. V., Kreher, K., Thomas, A. J., Robinson, A. D., Harris, N. R. P., Johnson, R., and Wilson, S. R.: Boundary layer new particle formation over East Antarctic sea ice - possible Hg-driven nucleation?, Atmos. Chem. Phys., 15, 13339-13364, https://doi.org/10.5194/acp-15-133392015, 2015.

(59) Jokinen, T., M. Sipilä, J. Kontkanen, V. Vakkari, P. Tisler, E.-M. Duplissy, H. Junninen, J. Kangasluoma, H. E. Manninen, T. Petäjä, M. Kulmala, D. R. Worsnop, J. Kirkby, A. Virkkula and V.-M. Kerminen, Ioninduced sulfuric acid-ammonia nucleation drives particle formation in coastal Antarctica Science Advances 28 Nov 2018: Vol. 4, no. 11, eaat9744 DOI: 10.1126/sciadv.aat9744 (2018).

(60) Leng, C., Kish, J.D., Roberts, J.E., Dwebi, I., Chon, N., Liu, Y., Temperature-dependent Henry's law constants of atmospheric amines. $\underline{J}$. Phys. Chem. A. 2015, 119, 8884-8891.

(61) Fountoukis, C. and Nenes, A., ISORROPIA II: a computationally efficient thermodynamic equilibrium model for $\mathrm{K}+-\mathrm{Ca} 2+-\mathrm{Mg} 2+-\mathrm{NH} 4+-\mathrm{Na}+-$ SO42--NO3--Cl--H2O aerosols, Atmos. Chem. Phys., 2007, 7, 4639-4659, https://doi.org/10.5194/acp-7-4639-2007.

(62) Guo, H., Xu, L., Bougiatioti, A., Cerully, K. M., Capps, S. L., Hite Jr., J. R., Carlton, A. G., Lee, S.-H., Bergin, M. H., Ng, N. L., Nenes, A., and Weber, R. J., Fine-particle water and $\mathrm{pH}$ in the southeastern United States, Atmos. Chem. Phys., 2015, 15, 5211-5228, https://doi.org/10.5194/acp-155211-2015.

(63) Gibb, S. W.; Mantoura, C.; Liss, P., Ocean-Atmosphere Exchange and Atmospheric Speciation of Ammonia and Methylamines in the Region of the NW Arabian Sea. Global Biogeochem. Cycles 1999, 13 (1), $161-178$.

(64) Hu, Q.J., Yu, P.R., Zhu, Y.J., Li, K., Gao, H.W., Yao, X.H., Concentration, size distribution, and formation of trimethylaminium and dimethylaminium ions in atmospheric particles over marginal seas of China. $\underline{J}$. Atmos. Sci. 2015, 72, 3487-3498.

(65) Yu, P.R., Hu, Q.J., Li, K., Zhu, Y.J., Liu, X.H., Gao, H.W., Yao, X.H., Characteristics of dimethylaminium and trimethylaminium in atmospheric particles ranging from supermicron to nanometer sizes over eutrophic marginal seas of China and oligotrophic open oceans. Sci. Total. Environ 2016, . 572, 813-824.

(66) Müller, C., linuma, Y., Karstensen, J., van Pinxteren, D., Lehmann, S., Gnauk, T., and Herrmann, H., Seasonal variation of aliphatic amines in marine sub-micrometer particles at the Cape Verde islands, Atmos. Chem. Phys., 2009, 9, 9587-9597, https://doi.org/10.5194/acp-9-9587-2009.

(67) Legrand, M., Ducroz, F., Wagenbach, D., Mulvaney, R., and Hall, J., Ammonium in coastal Antarctic aerosol and snow: Role of polar ocean and 
penguin emissions, J. Geophys. Res.-Atmos., 1998, 103, 11043-11056, https://doi.org/10.1029/97jd01976.

(68) Speir, T. W., and J. C. Cowling, Ornithogenic soils of the Cape Bird Adelie penguin rookeries, Antarctica. 1. Chemical properties, Polar Biol.,1984, 2, 199-205, doi:10.1007/BF00263625.

(69) Ge X, Wexler AS, Clegg SL., Atmospheric amines-part I. A review. Atmos. Environ., 2011, 45(3):524-546. doi:10.1016/j.atmosenv. 2010.10.012

(70) Almeida, J. et al., Molecular understanding of sulphuric acidamine particle nucleation in the atmosphere. Nature, 2013, 502, 359-363.

(71) Weller, R., Minikin, A., Wagenbach, D., and Dreiling, V., Characterization of the inter-annual, seasonal, and diurnal variations of condensation particle concentrations at Neumayer, Antarctica, Atmos. Chem. Phys., 2011, 11, 13243-13257, https://doi.org/10.5194/acp-11-13243-2011.

(72) Kim, J., Yoon, Y. J., Gim, Y., Kang, H. J., Choi, J. H., Park, K.-T., and Lee, B. Y., Seasonal variations in physical characteristics of aerosol particles at the King Sejong Station, Antarctic Peninsula, Atmos. Chem. Phys., 2017, 17, 12985-12999, https://doi.org/10.5194/acp-17-12985-2017.

(73) Jokinen, T., Sipilä, M., Junninen, H., Ehn, M., Lönn, G., Hakala, J., Petäjä, T., Mauldin III, R. L., Kulmala, M., and Worsnop, D. R., Atmospheric sulphuric acid and neutral cluster measurements using Cl-APi-TOF, Atmos. Chem. Phys., 2012, 12, 4117-4125, https://doi.org/10.5194/acp-12-4117-2012. 


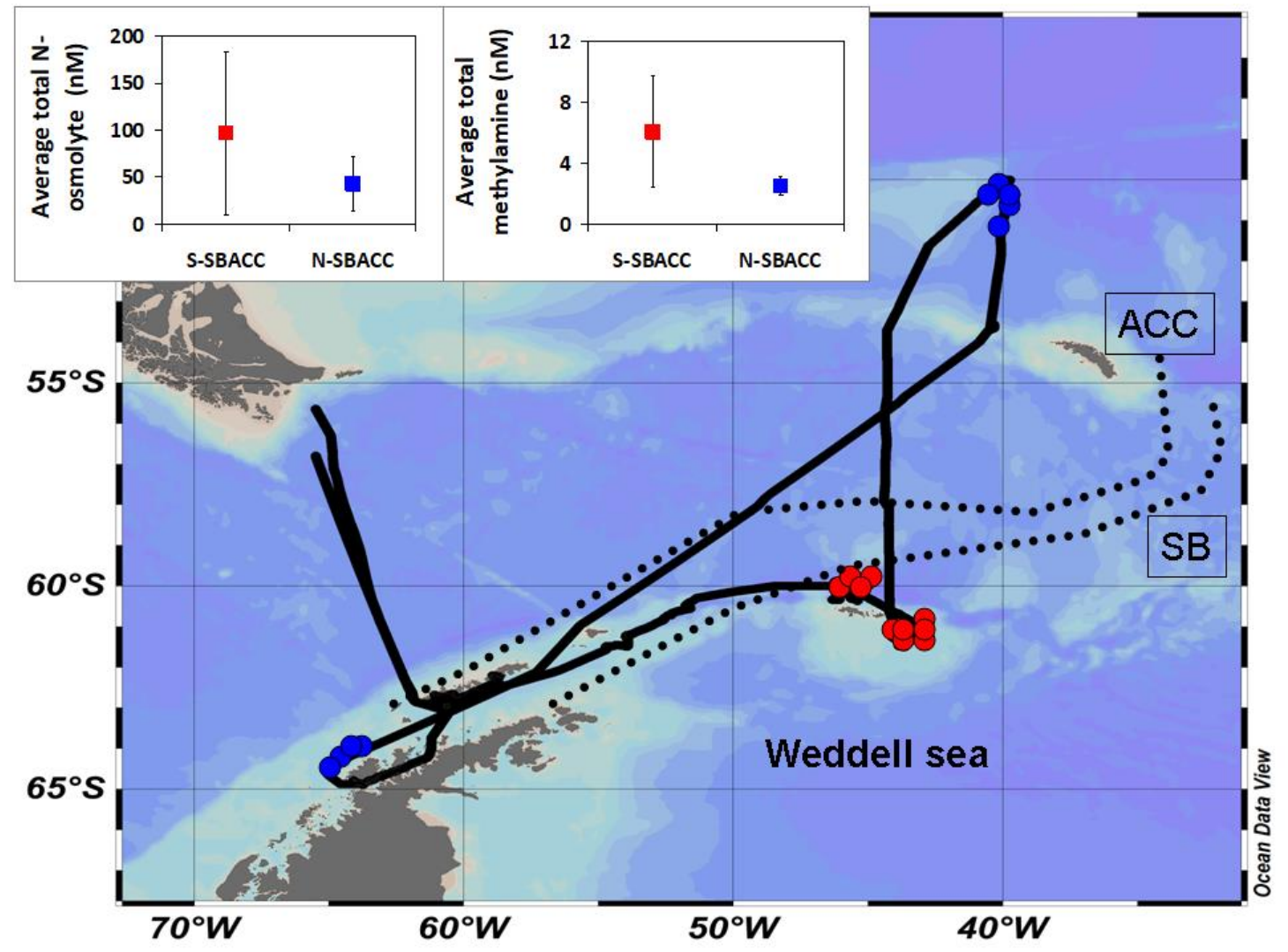

Fig. 1 Map of the study region. The black solid line is the cruise track. Approximate synoptic locations of the main hydrographic fronts are indicated with dashed lines: Antarctic Circumpolar Current (ACC) and Southern Boundary (SB). SBACC stands for Southern ACC and SB fronts. In red dots are water sampling stations south of the SBACC, whereas in blue are stations north of the SBACC. Top Fig.s: concentrations (average, standard deviation) of particulate $\mathrm{N}$-osmolites and dissolved alkyilamines in surface seawater. Average total $\mathrm{N}$-osmolyte concentration (glycine betaine+choline; red), and average total methylamine concentration (monomethylamine + dimethylamine + trimethylamine; blue) are shown south $(\mathrm{S})$ and north $(\mathrm{N})$ of the southern boundary of the Antarctic Circumpolar Current (SBACC). 


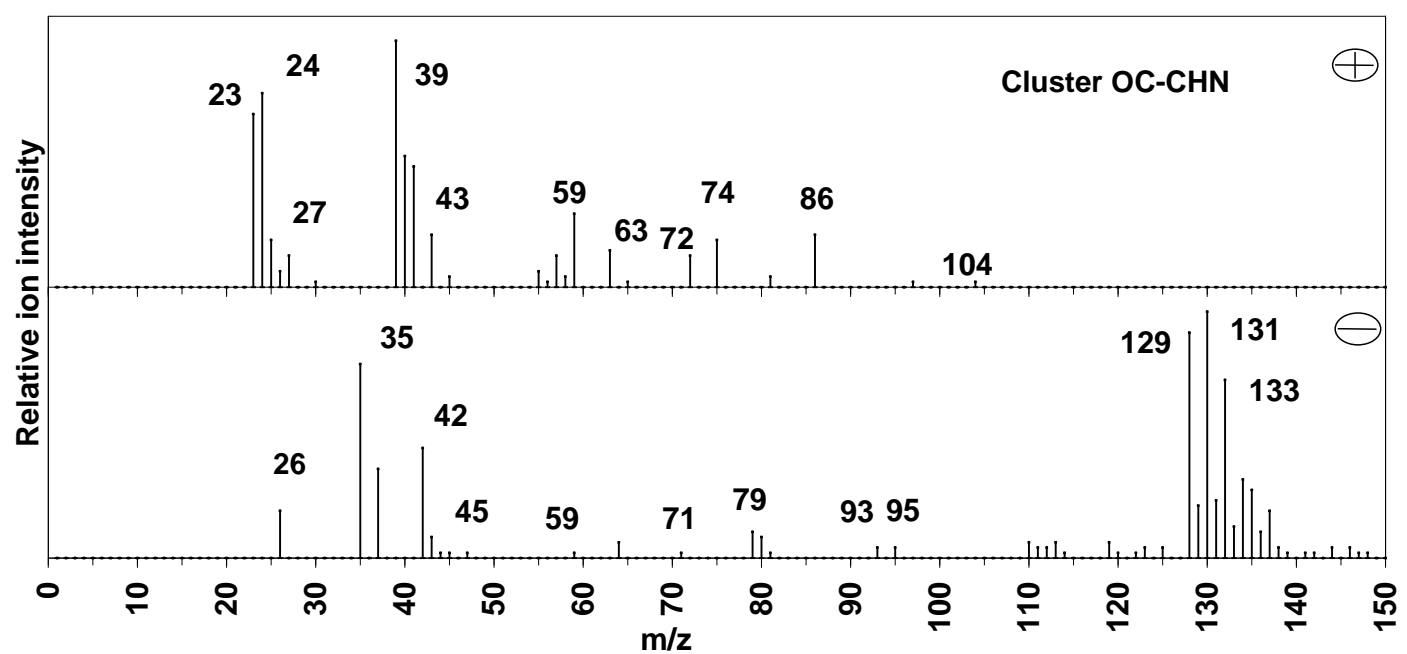

(a) $\mathrm{OC}-\mathrm{CHN}$

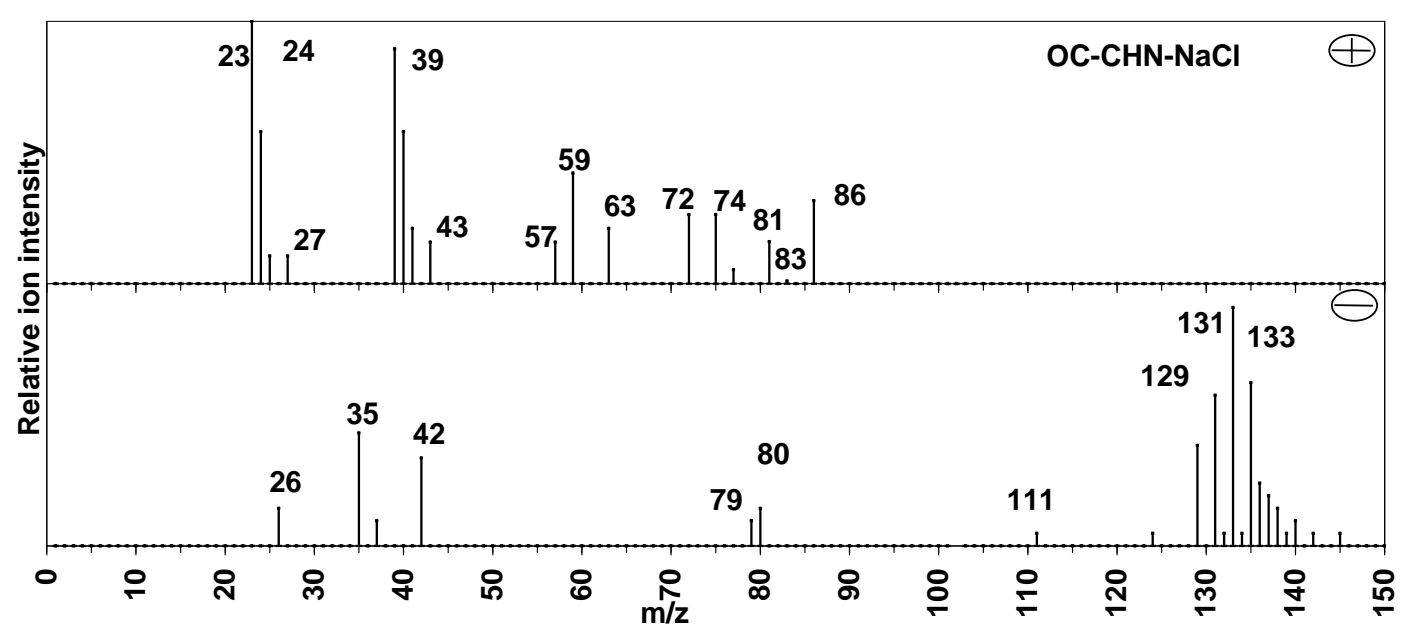

(b) $\mathrm{OC}-\mathrm{CHN}-\mathrm{NaCl}$ 


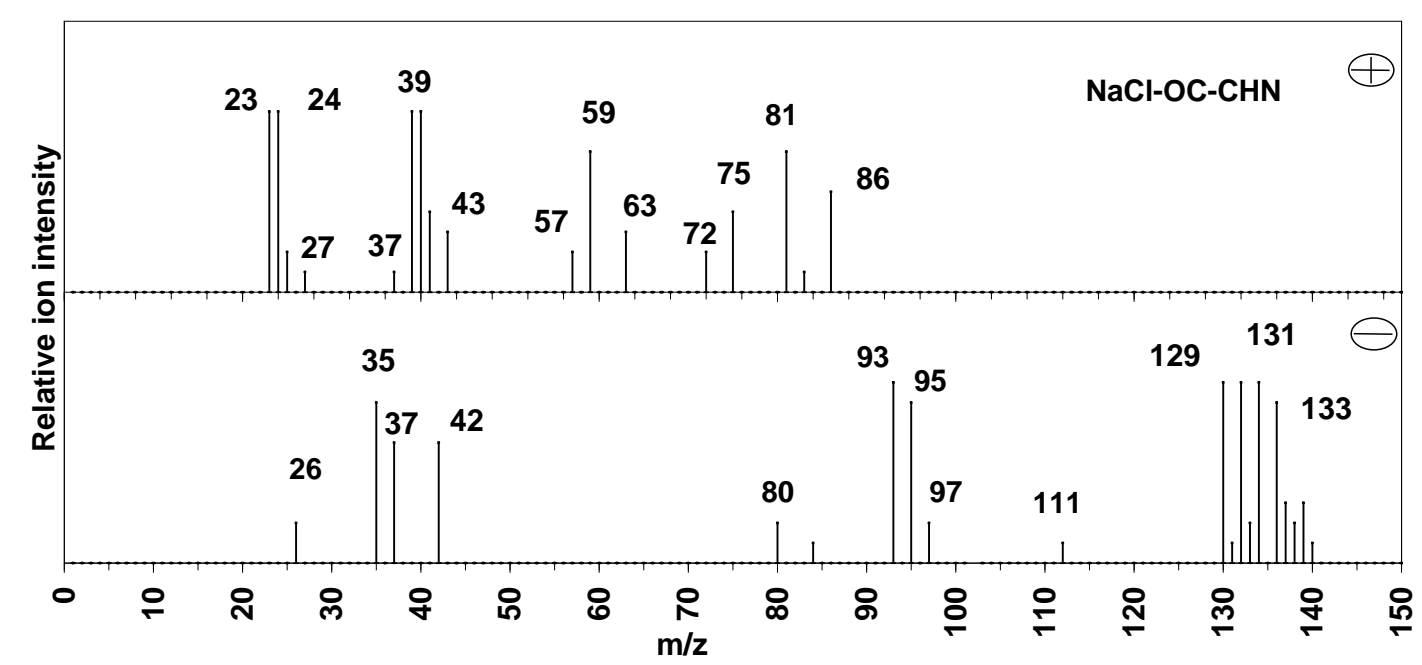

(c) $\mathrm{NaCl}-\mathrm{OC}-\mathrm{CHN}$

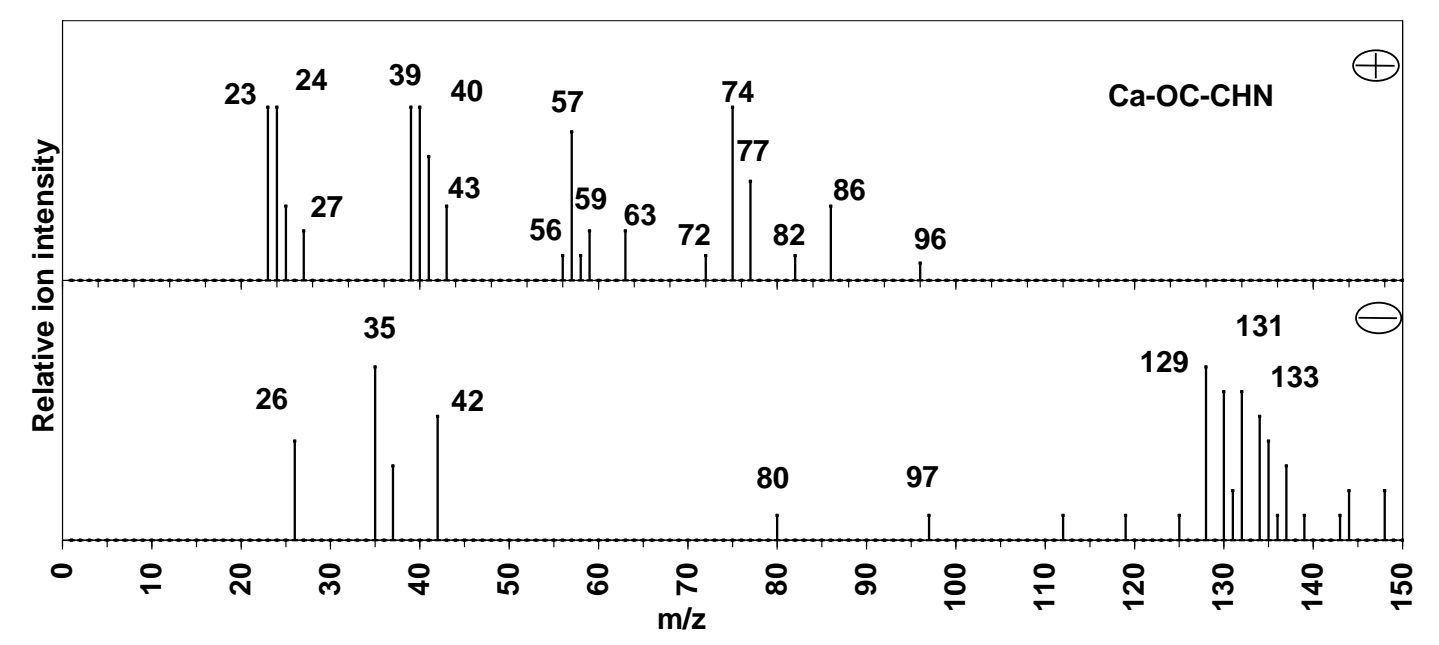

(d) $\mathrm{Ca}-\mathrm{OC}-\mathrm{CHN}$

Fig. 2 Positive and Negative ART-2a area vectors attributed to (a) OC-CHN, (b) OC-CHN-NaCl, (c) ) NaCl-OC-CHN and (d) Ca-OC-CHN. 


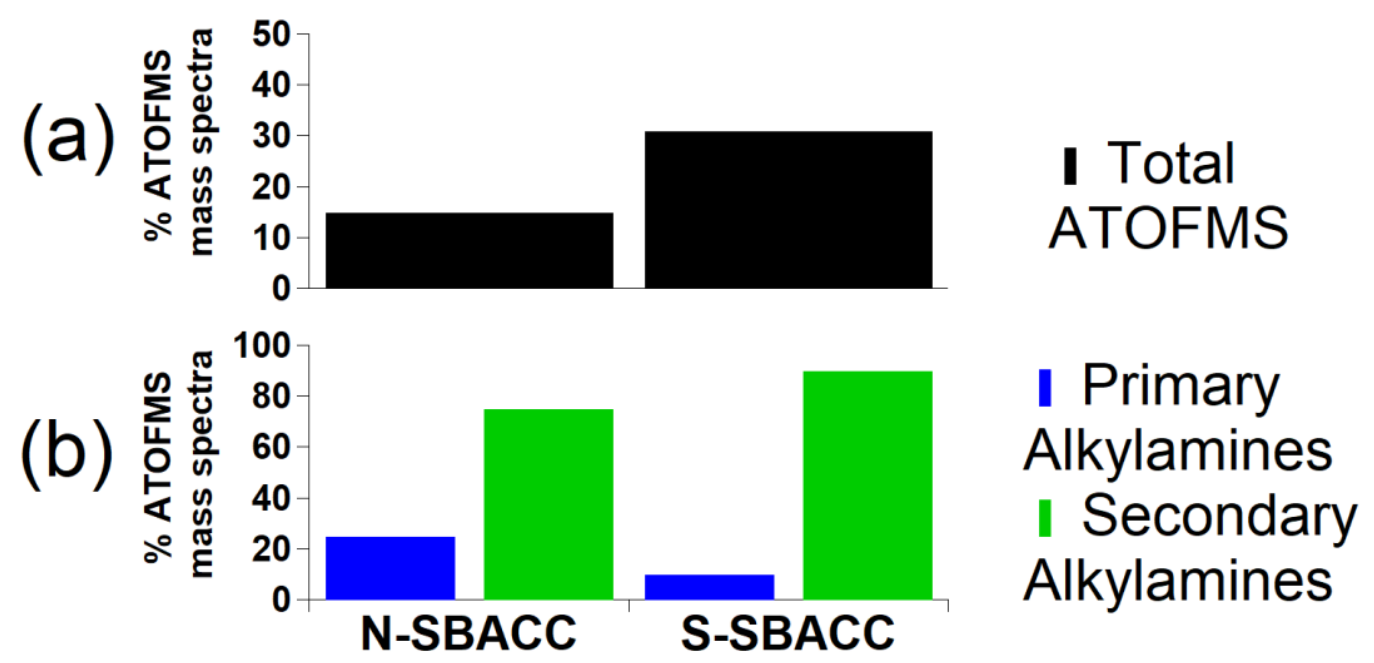

Fig. 3 Percentages of the total number of ATOFMS organic particles containing alkylamines; detected from air masses originated in North and South SBACC fronts (a) and percentages of these particles internally mixed with sea spray (b), respectively. 


\section{SUPPORTING INFORMATION}

Figure S1-S2: aerosol size distributions and mass spectra of ATOFMS

Table S1-S3: Alkylamines-ions concentrations and selected variables during the PEGASO cruise 
"For TOC Only".

\section{Alkylamines (atmosphere)}

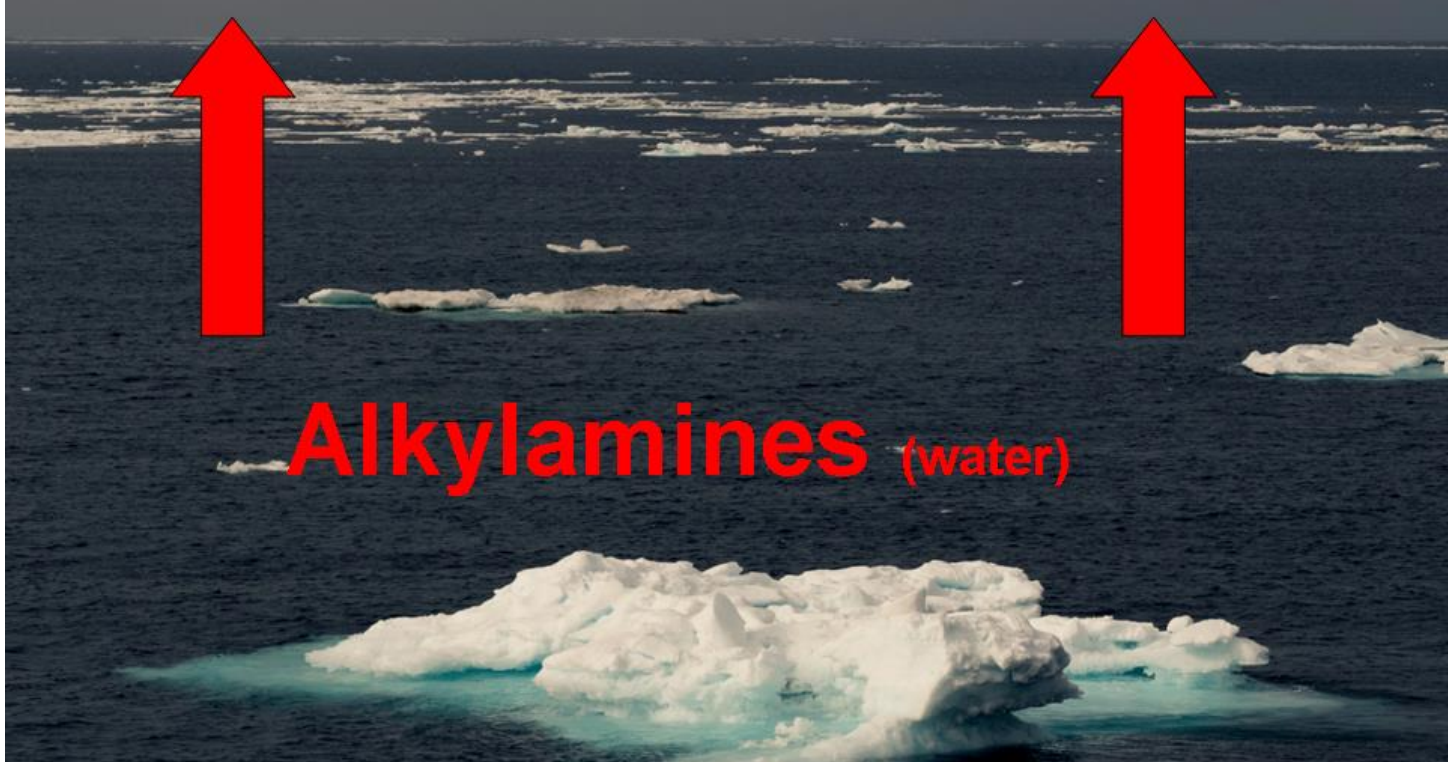

